Idarotuna Vol. 1, No. 2, April 2019

\title{
STRATEGI PENGELOLAAN ZAKAT BERBASIS PEMBERDAYAAN MASYARAKAT MISKIN PADA BADAN AMIL ZAKAT NASIONAL (BAZNAS) KOTA PEKANBARU
}

\author{
Artis \\ Fakultas Dakwah dan Komunikasi, UIN Suska Riau \\ Email: artis@uin-suska.ac.id
}

\begin{abstract}
Abstrak
Penelitian ini dilakukan pada Badan Amil Zakat Nasional (BAZNAS) Kota Pekanbaru.Permasalahan dalam penelitian ini adalah bagaimana strategi pengelolaan zakat berbasis pemberdayaan masyarakat miskin yang diterapkan oleh Badan Amil Zakat Nasional (BAZNAS) Kota Pekanbaru dengan tujuan agar strategi pengelolaan tersebut dapat diketahui.Informan penelitian ini berjumlah 10 orang.Metode pengumpulan data dilakukan melalui observasi, wawancara, dan dokumentasi dan dianalisis secara deskriptif kualitatif. Berdasarkan metode di atas dapat ditemukan bahwa strategi pengelolaan zakat berbasis pemberdayaan masyarakat miskin pada Badan Amil Zakat Nasional (BAZNAS) Kota Pekanbaru dilakukan tahapan perencanaan, pengidentifikasian, pendistribusian, pengawasan dan evaluasi. Perencanaan dibentuk dengan cara menyusun program kerja yang berpihak pada masyarakat miskin. Pengidentifikasian dilakukan dengan cara pengumpulan data muzakki dan mustahik terutama orang-orang miskin. Pendistribusian disalurkan dengan cara menyalurkan ke sektor produktif dengan tujuan agar masyarakat miskin menjadi berdaya. Pengawasan dilakukan dengan cara menjamin tercapainya pengentasan kemiskinan sesuai rencana. Sedangkan evaluasi dilakukan dengan cara penilaian dalam mengawasi proses agar tidak terjadi penyimpangan. Cara tersebut terkoordinir dengan sistematis, meski masih ada hal-hal yang harus dibenahi. Namun, secara keseluruhan strategi pengelolaan zakat berbasis pemberdayaan masyarakat miskin telah berjalan sesuai dengan ketentuan syari'at agama Islam, Undang-Undang (UU) zakat dan ilmu dalam pengelolaan zakat.
\end{abstract}

Kata Kunci: Pengelolaan Zakat, Pemberdayaan, Masyarakat Miskin 


\section{Pendahuluan}

Pada akhir dekade 90-an, tepatnya pada tahun 1999, pengelolaan zakat mulai memasuki level negara, setelah sebelumnya hanya berkutat pada tataran masyarakat.Hal tersebut ditandai dengan disahkannya Undang-Undang (UU) No. 38/1999 tentang Pengelolaan Zakat.Setelah itu, diamandemen Undang-Undang (UU) No. 23/2011 tentang Pengelolaan Zakat.UndangUndang (UU) inilah yang menjadi landasan legal formal pelaksanaan zakat di Indonesia.Dalam upaya pengumpulan zakat, pemerintah telah mengukuhkan Badan Amil Zakat Nasional (BAZNAS), yaitu, lembaga pengelolaan zakat yang dibentuk oleh pemerintah, yang personalia pengurusnya terdiri atas ulama, cendekiawan, profesional, tokoh masyarakat, dan unsur pemerintah.

Selanjutnya, berdasarkan keputusan Menteri Agama RI tentang pelaksanaan Undang-Undang (UU) No.688 Tahun 1999 tentang pengelolaan zakat disebutkan pada pasal 28 mengenai susunan organisasi poin 2 Badan Amil Zakat Nasional (BAZNAS) mempunyai susunan hirarki mulai dari Badan Amil Zakat Nasional (BAZNAS) dibentuk oleh Menteri Agama, Badan Amil Zakat Nasional (BAZNAS) yang berkedudukan di ibu Kota Provinsi dibentuk oleh gubernur atas usul dari Kepala Kantor Wilayah Departemen Agama Provinsi, Badan Amil Zakat Nasional (BAZNAS) yang berkedudukan di daerah Kabupaten atau Kota, dilakukan oleh bupati atau walikota atas usul kepala kantor wilayah Departemen Agama Kabupaten/Kota dan Badan Amil Zakat Nasional (BAZNAS) kecamatan yang berkedudukan di ibu Kota Kecamatan dibentuk oleh Camat atas usul dari dari Kantor Urusan Agama Kecamatan.

Badan Amil Zakat Nasional (BAZNAS) Pekanbaru sejauh ini belum memiliki data akurat berapa jumlah ril warga miskin Kota Pekanbaru. Oleh karena itu, Badan Amil Zakat Nasional (BAZNAS) membentuk tim pengentasan kemiskinan demi menekan jumlah warga miskin di wilayah ini tahun 2016 sebesar 27,73 juta orang atau 10,96 persen, menurun dari tahun lalu yang tercatat 28,6 juta orang atau 11,46 persen.

Dari jumlah penduduk tersebut,bahwa potensi Zakat di Kota Pekanbaru adalah Rp.1.908.354.800.000,00 setiap tahunnya.Jumlah ini adalah potensi yang sangat besar, bila dikaitkan dengan zakat fitrah dan zakat maal.Dari sisi zakat fitrah, apabila seluruh umat Islam Kota Pekanbaru membayar zakat fitrahnya ratarata Rp.20.000,00 per jiwa, maka akan terkumpul dana sebesar Rp.100.439.720.000,00 (Seratus milliar empat ratus tiga puluh sembilan juta tujuh ratus dua puluh ribu rupiah). Dari sisi zakat maal, apabila 25 persen dari total umat Islam atau 1.255.497 jiwa, membayarkan zakat maalnya sebesar Rp.1.200.000,00 (Satu juta dua ratus ribu rupiah) setiap tahun, maka akan terkumpul dana sebesar Rp.1.506.595.800.000,00 (Satu triliun lima ratus enam milliar lima ratus sembilan puluh lima juta delapan ratus ribu rupiah).Bertitik tolak dari latar belakang diatas, perlu dikaji lebih lanjut dengan melakukan penelitian yang berjudul "Strategi Pengelolaan Zakat Berbasis Pemberdayaan Masyarakat Miskin pada Badan Amil Zakat Nasional (BAZNAS) 
Dalam identifikasi masalah ditemukan persoalan kurangnya upaya pengelolaan zakat yang dilakukan oleh Badan Amil Zakat Nasional (BAZNAS) Kota Pekanbaru, adanya ketidaksesuaian pengumpulan zakat yang dilakukan oleh Badan Amil Zakat Nasional (BAZNAS) Kota Pekanbaru, adanya ketidaksesuaian pendistribusian zakat kepada masyarakat Kota Pekanbaru yang dilakukan oleh Badan Amil Zakat Nasional (BAZNAS), dan kurangnya pendayagunaan zakat yang dilakukan oleh Badan Amil Zakat Nasional (BAZNAS) Kota Pekanbaru.

Pada batasan masalah penelitian ini hanya terbatas pada strategi pengelolaan Badan Amil Zakat Nasional (BAZNAS) Kota Pekanbaru dalam mengelola zakat berbasis masyarakat miskin. Dalam rumusan masalah penelitian ini memfokuskan pada bagaimana strategi pengelolaan zakat berbasis pemberdayaan masyarakat miskin pada Badan Amil Zakat Nasional (BAZNAS) Kota Pekanbaru ?

Tujuan dalam penelitian ini adalah untuk mengetahui strategi pengelolaan zakat berbasis pemberdayaan masyarakat miskin pada Badan Amil Zakat Nasional (BAZNAS) Kota Pekanbaru dan kegunaanya sebagai bahan informasi ilmiah bagi peneliti-peneliti yang ingin mengetahui strategi mengelola zakat berbasis pemberdayaan masyarakat miskin dan juga dapat menjadi rujukan dalam melakukan penelitian-penelitian serupa.

Berdasarkan permasalahan dan tujuan penelitian yang telah dirumuskan, maka jenis penelitian ini adalah penelitian kualitatif.Penelitian kualitatif merupakan salah satu jenis penelitian yang bertujuan mendeskripsikan secara sistematis dan faktual mengenai fakta-fakta dan menggambarkan fenomena secara detail, dimana metode penelitian kualitatif ini dilakukan dengan menggunakan data yang dicatat bukan dengan angka-angka tetapi menggunakan klarifikasi-klarifikasi yang dipaparkan secara deskriptif.

Sumber data penelitian ini berasal dari data primer, yaitu data yang diperoleh melalui wawancara. Selain itu, data penelitian ini juga berasal dari data sekunder, yaitu data yang diperoleh melalui observasi dan dokumentasi berupa laporanlaporan buku-buku, buletin, dan lain-lain yang terkait dengan permasalahan peneliti dan teknik pengumpulan data adalah:

a. Observasi, yaitu kegiatan yang dilakukan oleh penulis dalam melakukan penelitian dengan cara mencatat secara sistematis terhadap gejala-gejala yang terdapat pada objek penelitian.

b. Wawancara, yaitu sejumlah pertanyaan yang diajukan untuk mengetahui strategi pengelolaan zakat yang dilakukan oleh Badan Amil Zakat Nasional (BAZNAS) Kota Pekanbaru.

c. Dokumentasi, yaitu merupakan kegiatan pencatatanpengumpulan dokumen atau berkas yang penting yang masih berhubungan dengan penelitian.

Analisis data merupakan bagian yang amat penting dalam metode ilmiah, karena dengan analisis data tersebut dapat diberi arti dan makna yang berguna dalam memecahkan masalah penelitian.Penelitian ini adalah penelitian yang bersifat deskriptif kualitatif yaitu menggambarkan atau memaparkan fenomena-fenomena dengan kata-kata atau kalimat, kemudian data-data tersebut dianalisis untuk memperoleh kesimpulan.

\section{Strategi Pengelolaan Zakat}

Berdasarkan hasil penelitian terhadap pengurus BAZNAS cabang Pekanbaru yang terkait dengan strategi pengelolaan zakat berbasis pemberdayaan masyarakat miskin, ibu Jumiarsih menjelaskan langkah yang diambil BAZNAS adalah merumuskan keadaan atau kondisi zakat dan membuat 
program jangka pendek, program jangka menengah, dan program jangka panjang.

a. Program Jangka Pendek

Program jangka pendek meliputi beberapa hal, yakni Pertama, membentuk unit pengumpul zakat (UPZ) padadinas/badan/kantor/instansi di Kota Pekanbaru.Kedua, melaksanakan penyuluhan dan sosialisasi zakat padasekretariat/dinas/badan/kantor/instansi

tingkat Kota Pekanbaru yang telah ada maupun yang belum ada unit pengumpul zakatnya dalam rangka meningkatkan upaya pengumpulan dan pendayagunaan zakat, infaq dan shadaqah. Ketiga, Menyalurkan dana zakat bekerjasama dengan Kelurahan serta berkoordinasi dengan Badan Amil Zakat Nasional (BAZNAS) Kecamatan. Keempat, Melaksanakan pelatihan usaha kerajinan tangan untuk para mustahik (orang yang berhak menerima zakat) Program

a. Jangka Menengah,

Program jangka menengah Pertama, melaksanakan penyuluhan dan sosialisasi melalui media seperti RRI, RTV, Harian Riau Pos dan sebagainya.Kedua, mengumpulkan dan pembuatan data potensi zakat yang ada di lingkungan wewenang BAZNAS Kota Pekanbaru dalam rangka pembuatan peta zakat.Ketiga, melaksanakan sosialisasi dengan para pengusahapengusaha yang ada di wilayah Kota Pekanbaru. Keempat, mencetak kupon infaq dan shadaqah dalam rangka meningkatkan penerimaan infaq dan shadaqah.Kelima, melaksanakan gerakan infaq Rp.10.000 pada bulan Ramadhan bagi semua pegawai negeri sipil di /dinas/badan/kantor/instansi tingkat Kota Pekanbaru dengan rekomendasi walikota Pekanbaru. Keenam, Melaksanakan pertemuan dan silaturrahmi tahunan dengan unit pengumpul zakat yang ada di lingkungan BAZNAS Kota Pekanbaru.Ketujuh, melaksanakan pertemuan dengan BAZNAS Kecamatan dalam rangka peningkatan koordinasi dalam pengelolaan zakat. Kedelapan, membuat iklan reklame, mencetak liflet, booklet, brosur dan kalender tahunan

b. Program Jangka Panjang

Program jangka panjangPertama, Menetapkan dan memberikan nomor pokok wajib zakat kepada muzakki yang terdiri dari 14 digits. Kedua, Menyusun rancangan peraturan daerah Kota Pekanbaru tentang wajib zakat bagi muzakki dan pengelolaannya.Ketiga, Melaksanakan study banding untuk meningkatkan kinerja pengurus BAZNAS.Keempat, Melaksanakan Pelatihan Usaha Kerajinan Tangan untuk para mustahik yang bekerja sama dengan dinas sosial. Kelima, Membukausaha seperti Koperasi, percetakan dan sebagainya. Keenam, Melaksanakan gerakan infaq dan shadaqah pada bulan ramadhan. Ketujuh, pengadaan sarana dan prasarana seperti Mobil operasional, Komputer dan lain sebagainya.

\section{Strategi Mengidentifikasi Potensi Muzakki}

\section{Pengumpulan Muzakki}

Pertama, Pengumpulan zakat perusahaan yang diambil dari gaji karyawan sebesar 2,5\% pada setiap bulan oleh pengelola UPZ Kedua, Muzakki perseorangan merupakan dana zakat yang disetor muzakki atau dijemput petugas langsung kerumah muzakki.

2. Pengumpulan Mustahik, dalam hal ini diminta kepada instansi terkait diantaranya pihak kelurahan untuk mengirimkan masing-masing 4 orang fakir miskin.

\section{Strategi Distribusi Zakat}

Hasil wawancara dengan ibu Murhapitni, didalam undang-undang zakat, asnaf fakir dan miskin merupakan skala prioritas dalam penditribusian zakat.Jadi, dalam pendistribusian zakat harus dilandasi dengan aspek 
kemiskinan, karena memang yang berhak mendapatkan bantuan adalah mereka yang kurang mampu.

\section{Strategi Pengawasan}

Menurut Murhapitni, selaku kesekretariatan BAZNAS Kota Pekanbaru menjelaskan, anggota pengumpul zakat diawasi dan berkoordinasi dengan kepala bidangnya, begitu pula dengan bidang lain seperti bidang pendistribusian, pendayagunaan, pengelolaan, dan pengembangan, masing-masing kepala bidang akan melaporkan hasil kinerja mereka kepada ketua BAZNAS dan itu akan dievaluasi oleh ketua BAZNAS.Selanjutnya beliau jelaskan pengawasan dilakukan,Pertama, Mengawasi pelaksanaan rencana kerja yang telah disahkan.Kedua, Mengawasi pelaksanaan kebijakan-kebijakan yang telah ditetapkan oleh dewan pertimbangan.Ketiga, Mengawasi operasional kegiatan yang dilaksanakan badan pelaksana, yang mencakup pengumpulan, pendistribusian dan pendayagunaan.Keempat, Melakukan pemeriksaan operasional dan pemeriksaan syari'ah.

\section{Strategi Evaluasi}

Hasil wawancara dengan ibu Haryati menjelasakan, pengevaluasian yang dilakukan BAZNASselama ini adalah melihat hasil kinerja petugas dalam aspek manajemen, teknik produksi, pengembangan produk, kualitas kontrol, dan organisasi bisnis.

\section{Bidang Perencanaan Pengelolaan}

Semua perencanaan kegiatan dalam mengelola Badan Amil Zakat Nasional (BAZNAS) Kota Pekanbaru telah merumuskan perencanaan sesuai dengan strategi pengelolaan yang sesungguhnya.Hal ini dapat dilihat bahwa, perencanaan di Badan Amil Zakat Nasional (BAZNAS) sudah berjalan dengan baik dan sesuai dengan kebutuhan organisasi tersebut, karena perencanaan yang disusun bertujuan untuk peningkatan kinerja dalam pelaksanaan program kerja.Khususnya untuk meningkatkan kesejahteraan masyarakat yang belakangan mengalami krisis terutama bagian ekonomi. Namun, dengan adanya perencanaan pengolaan program kerja yang strategis dan matang dalam menjalankan setiap kegiatan maka akan sangat membantu peningkatan ekonomi kepada seluruh masyarakat muslim yang membutuhkan zakat.

\section{Bidang Identifikasi Muzakki}

Identifikasi potensi zakat adalah

proses atau cara mengalokasikan sumber daya manusia dan menetapkan tugas. Agar pelaksanaan pencapaian tujuan zakat menjadi lebih baik, maka ada kegiatan perekrutan, penyeleksian pelatihan dan pengembangan sumber daya manusia. Sehingga sumber daya manusia dapat ditempatkan pada posisi yang tepat.

Untuk mencapai tujuan utama Badan Amil Zakat Nasional (BAZNAS) Kota Pekanbaru, pengurus Badan Amil Zakat Nasional (BAZNAS) mengidentifikasi potensi zakat yang terdiri dari pengumpulan muzakki dan pengumpulan mustahik. pengumpulan muzakki merupakan pengumpulan yang dilakukan dengan melalui perusahaan, perseorangan dan hasil penempatan. Sedangkan pengumpulan mustahik merupakan pengumpulan yang dilakukan untuk mengirimkan fakir miskin, muallaf, sabilillah dan ibnu sabil.Pembagian ini dilakukan untuk tercapai tujuan utama Badan Amil Zakat Nasional (BAZNAS).

\section{A. Bidang Distribusi}

Pendistribusian zakat berdasarkan skala prioritas yang dilakukan oleh pengurus Badan Amil Zakat Nasional (BAZNAS) Kota 
Pekanbaru kepada asnaf fakir dan miskin sudah tepat karena sesuai dengan amanat Undang-Undang (UU) zakat No.38 tahun 1999 bahwa pendistribusian atau pendayagunaan hasil pengumpulan zakat berdasarkan skala prioritas kebutuhan mustahik dan dimanfaatkan untuk usaha yang produktif. Sasaran dan tujuan pendistribusian zakat oleh Badan Amil Zakat Nasional (BAZNAS) Kota Pekanbaru diharapkan dapat mensucikan harta umat dan mengangkat taraf kehidupan masyarakat,

\section{Bidang Pengawasan}

Untuk mencegah terjadinya penyimpangan-penyimpangan baik disengaja atau tidak agar segera dapat diambil langkah-langkah yang berguna untuk mencegah kerugian yang berkelangsungan, begitu juga untuk memulai keunggulan rencana yang telah dibuat, langkah selanjutnya adalah melaksanakan

pengawasan (controlling).Cara pengawasan Badan Amil Zakat Nasional (BAZNAS) dilakukan secara berjenjang.Badan pengawas yang telah dibentuk diberi tugas untuk kegiatan umum, dan bagianbagian dibawahnya diawasi oleh pengurus inti, sedangkan kepala bagian masing-masing diberikan tugas untuk mengawasi kegiatan-kegiatan para bawahannya dalam melaksanakan kinerja.Pengawasan dilakukan secara menyeluruh baik secara administratif, organisasi dan keuangan.Pengawasan juga dilakukan dengan adanya pelaporan dari Badan Amil Zakat Nasional (BAZNAS) Kota Pekanbaru ke Badan Amil Zakat Nasional (BAZNAS) Provinsi.Sehingga, pada akhirnya kegiatan-kegiatan yang telah direncanakan terlaksanakan dengan baik dan mencapai hasil yang diinginkan dan mendapatkan nilai yang lebih baik dari sebelumnya.Dari hasil pengawasan yang dilakukan oleh pihak Badan Amil Zakat Nasional (BAZNAS) terlihat jelas peningkatan kinerja para petugas mulai meningkat meskipun mengalami beberapa kendalanamun dengan berjalannya pelaksanaan perencanaan kegiatan semua terealisasikan dengan baik.

\section{Bidang Evaluasi}

Evaluasi merupakan penilaian yang dilakukan oleh Badan Amil Zakat Nasional (BAZNAS) dalam ekonomi masyarakat miskin.Pertama, peningkatan sumber daya manusia termasuk dalam aspek manajemen, teknik produksi, pengembangan produk, kualitas kontrol, dan organisasi bisnis. Untuk meningkatkan sumber daya manusia ini, memberikan pelatihan langsung kepada pengusaha sangat penting dan ini merupakan satu-satunya cara yang paling efektif. Kedua, meningkatkan teknologi, teknologi merupakan kemampuan teknik berdasarkan ilmu teknik.Teknologi sangat dibutuhkan oleh semua orang, termasuk masyarakat miskin.Keterbatasan teknologi masyarakat miskin, disebabkan oleh keterbatasan informasi mengenai mesin atau alat produksi baru dan keterbatasan Sumber Daya Manusia (SDM) yang dapat mengoperasikan mesin-mesin atau melakukan inovasi dalam produk maupun proses produksi.Rendahnya penguasaan teknologi modern juga merupakan suatu ancaman serius bagi masyarakat miskin.

Faktor-faktor yang Mempengaruhi Pengelolaan Zakat

Adapun faktor pendukung pengelolaan zakat berbasis pemberdayaan masyarakat miskin Pada BAZNAS) antara lain: 
1. Mempunyai infrastruktur yang memadai dalam pemberdayaan masyarakat miskin.

2. Menjalin hubungan baik dengan instansi-instansi terkait.

3. Memiliki media atau website dalam menyampaikan informasi zakat.

4. Pemerintah mendukung kebijakan Badan Amil Zakat Nasional (BAZNAS) Kota Pekanbaru.

Dan faktor penghambat pengelolaan zakat berbasis pemberdayaan masyarakat miskin Pada BAZNAS) antara lain :

1. Kurangnya tenaga pengurus dalam mencari dana zakat.

2. Pengembalian pinjaman yang tidak sesuai jadwal dan Mustahik yang kurang disiplin dan bertanggung jawab.

\section{Kesimpulan}

Pengelolaan zakat berbasis pemberdayaan masyarakat miskin pada Badan Amil Zakat Nasional (BAZNAS) Kota Pekanbaru telah dilakukan dengan strategi yang jelasmeliputi perencanaanyaitu menyusun program kerja yang berpihak pada masyarakat miskin. Pengidentifikasian yaitu pengumpulan data muzakki dan mustahik terutama orang-orang miskin. Pendistribusian disalurkan dengan cara menyalurkan ke sektor produktif dengan tujuan agar masyarakat miskin menjadi berdaya. Pengawasan dilakukan dengan cara menjamin tercapainya pengentasan kemiskinan sesuai rencana. Sedangkan evaluasi dilakukan dengan cara penilaian dalam mengawasi proses agar tidak terjadi penyimpangan. Cara di atas terkoordinir dengan sistematis, meski masih ada hal-hal yang harus dibenahi. Namun, secara keseluruhan strategi pengelolaan zakat berbasis pemberdayaan masyarakat miskin telah berjalan sesuai dengan ketentuan syari'at agama Islam, Undang-Undang (UU) zakat dan ilmu dalam pengelolaan zakat.

\section{DAFTAR PUSTAKA}

Abu Zahrah, Muhammad. (1995). Zakat dalam Perspektif Sosial. Jakarta: Pustaka Firdaus.

Ahmad Supardi, Hasibuan. (2003). Pemberdayaan Zakat.Pekanbaru: PT. Erlangga.

Arief, Suadi. (1999). Sistem Pengendalian Manajemen. Yogyakarta: PT. BPFE.

Arikunto, Suharsimi. (1993). Metodologi Penelitian.Jakarta: PT. Raja Grafindo Persada.

Daud, Ali. (1998). Manajemen Zakat. Pekanbaru: PT. Suska Press.

Departemen Agama RI. (2008). Pemberdayaan Zakat dalam Islam.Kuwait: PT. Insan Media.

Depag RI, UU No. 38 Tahun 1999.Tentang PengelolaanZakat Bab VI : 11.

Hamid Mahmud Al-Ba'ly, Abdul. 2006. Ekonomi Zakat. Jakarta: PT. Raja Grafindo Persada.

Kohar, Abdul. (1998). Badan Amil Zakat.Jakarta: PT. Gema Insani.

Peter, Baldock. (2008). Ilmu Pemberdayaan Masyarakat Miskin.Jakarta: PT. Rajawali Pers.

Ridwan, Ahmad. (2008). Pemberdayaan Masyarakat Miskin.Jakarta: PT. Rajawali Pers. 
Idarotuna Vol. 1, No. 2, April 2019

Sani, Ridwan. (2008). Pemberdayaan Masyarakat Miskin.Jakarta: PT. Rajawali Pers.

Suharto, Edi. (2009). Kemiskinan dan Perlindungan Sosial di Indonesia. Bandung: PT. Alfabeta.

Soedjono.(2008). Pemberdayaan

Masyarakat Miskin.Jakarta: PT.

Rajawali Pers. 